SAND82-7121

Unlimited Release

UC-63b

\title{
Design and Development of a Laminated Glass-Plastic Fresnel Lens for Point Focus Photovoltaic Systems
}

\section{A. Matalon}

Swedlow, Inc.

Garden Grove, CA 92645

Prepared by Sandia National Laboratories Albuquerque, New Mexico 87185 and Livermore, California 94550 for the United States Department of Energy under Contract DE-AC04-76DP00789

Printed August 1982 


\section{DISCLAIMER}

This report was prepared as an account of work sponsored by an agency of the United States Government. Neither the United States Government nor any agency Thereof, nor any of their employees, makes any warranty, express or implied, or assumes any legal liability or responsibility for the accuracy, completeness, or usefulness of any information, apparatus, product, or process disclosed, or represents that its use would not infringe privately owned rights. Reference herein to any specific commercial product, process, or service by trade name, trademark, manufacturer, or otherwise does not necessarily constitute or imply its endorsement, recommendation, or favoring by the United States Government or any agency thereof. The views and opinions of authors expressed herein do not necessarily state or reflect those of the United States Government or any agency thereof. 


\section{DISCLAIMER}

Portions of this document may be illegible in electronic image products. Images are produced from the best available original document. 
Issued by Sandia National Laboratories, operated for the United States Department of Energy by Sandia Corporation.

NOTICE: This report was prepared as an account of work sponsored by an agency of the United States Government. Neither the United States Government nor any agency thereof, nor any of their employees, nor any of their contractors, subcontractors, or their employees, makes any warranty, express or implied, or assumes any legal liability or responsibility for the accuracy, completeness, or usefulness of any information, apparatus, product, or procompleteness, or usefulness of any information, apparatus, product, or process disclosed, or represents that its use would not infringe privately owned rights. Reference herein to any specific commercial product, process, or
service by trade name, trademark, manufacturer, or otherwise, does not necessarily constitute or imply its endorsement, recommendation, or favoring by the United States Government, any agency thereof or any of their contractors or subcontractors. The views and opinions expressed herein do not necessarily state or reflect those of the United States Government, any agency thereof or any of their contractors or subcontractors.

Printed in the United States of America

Available from

National Technical Information Service

U.S. Department of Commerce

5285 Port Royal Road

Springfield, VA 22161

NTIS price codes

Printed copy: A03

Microfiche copy: A01 


\title{
Design and Development of a Laminated Glass-Plastic Fresnel Lens for Point Focus Photovoltaic Systems
}

\author{
L. A. Matalon \\ Swedlow, Inc. \\ Garden Grove, CA 92645
}

Sandia Contract No. $13-5165$

\begin{abstract}
The design and development of a laminated glass-plastic Fresnel lens for point focus photovoltaic systems use is described. The objective of this development was to examine the feasability of producing lenses with a cost effectiveness superior to that of lenses made by casting of acrylic. The procedure used in executing this development, the method used in cost effectiveness evaluation, results obtained and recommendations for further work are presented.
\end{abstract}

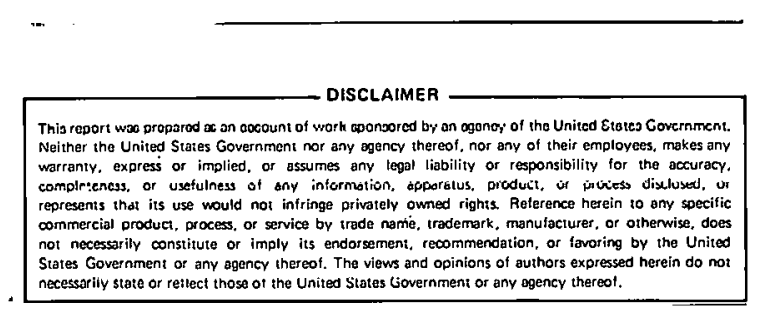




\section{TABLE OF CONTENTS}

TITLE

PAGE

INTRODUCTION $\ldots \ldots \ldots \ldots \ldots \ldots \ldots \ldots \ldots \ldots \ldots \ldots \ldots \ldots \ldots \ldots \ldots \ldots \ldots \ldots \ldots \ldots \ldots \ldots$

LENS ELEMENT GEOMETRY $\ldots \ldots \ldots \ldots \ldots \ldots \ldots \ldots \ldots \ldots \ldots \ldots \ldots \ldots \ldots \ldots \ldots \ldots$

EFFECT OF OPTICAL EFFICIENCY ON SYSTEM

COST EFFECTIVENESS $\ldots \ldots \ldots \ldots \ldots \ldots \ldots \ldots \ldots \ldots \ldots \ldots \ldots \ldots \ldots \ldots \ldots \ldots$

GLASS SELECTION $\ldots \ldots \ldots \ldots \ldots \ldots \ldots \ldots \ldots \ldots \ldots \ldots \ldots \ldots \ldots \ldots$

FACET MATERIAL SELECTION CONSIDERATION $\ldots \ldots \ldots \ldots \ldots \ldots \ldots \ldots \ldots$

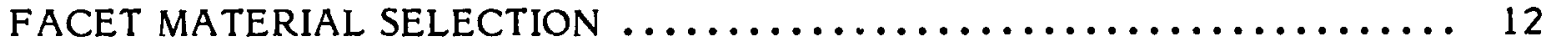

GENERAL TESTING $\ldots \ldots \ldots \ldots \ldots \ldots \ldots \ldots \ldots \ldots \ldots \ldots \ldots \ldots \ldots \ldots \ldots \ldots \ldots \ldots \ldots \ldots$

OPTICAL TESTING $\ldots \ldots \ldots \ldots \ldots \ldots \ldots \ldots \ldots \ldots \ldots \ldots \ldots \ldots \ldots \ldots \ldots \ldots$

LENS FABRICATION $\ldots \ldots \ldots \ldots \ldots \ldots \ldots \ldots \ldots \ldots \ldots \ldots \ldots \ldots \ldots \ldots \ldots \ldots$

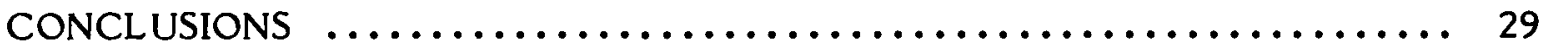

RECOMMENDATIONS FOR FURTHER WORK $\ldots \ldots \ldots \ldots \ldots \ldots \ldots \ldots \ldots$

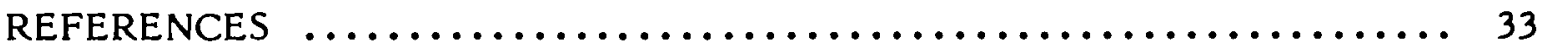

\section{LIST OF FIGURES}

FIGURE $1 \quad$ LENS ELEMENT GEOMETRY $\ldots \ldots \ldots \ldots \ldots \ldots \ldots \ldots \ldots \ldots$

FIGURE 2 CONCENTRATOR SYSTEM COSTS VS

LENS EFFICIENCY $\ldots \ldots \ldots \ldots \ldots \ldots \ldots \ldots \ldots \ldots \ldots \ldots \ldots \ldots \ldots \ldots \ldots$

FIGURE 3 GLASS STRESSED AND DEFLECTION VS NORMAL

WIND VELOCITY FOR A 34.5 INCH SQUARE PLATE $\ldots \ldots \ldots 9$

FIGURE 4 PRESS-CURED LAMINATED LENS

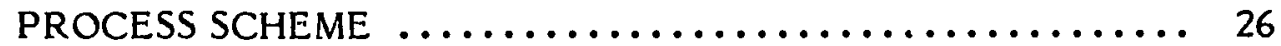


TABLE OF CONTENTS (CONT'D)

TABLE I CHARACTERISTICS OF LENS $\ldots \ldots \ldots \ldots \ldots \ldots \ldots \ldots \ldots, \ldots$

TABLE II COST \& LIGHT TRANSMITTANCE DATA

FOR CANDIDATE GLASS TYPES $\ldots \ldots \ldots \ldots \ldots \ldots \ldots \ldots, 8$

TABLE III MATERIAL GENERAL SCREENING $\ldots \ldots \ldots \ldots \ldots \ldots \ldots, 13$

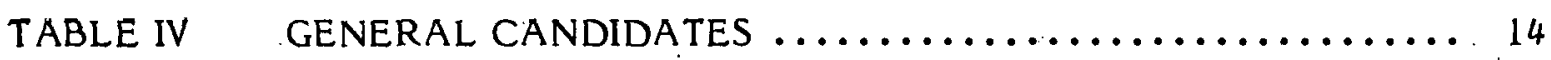

TABLE $V$ CANDIDATE MATERIALS FOR EVALUATION $\ldots \ldots \ldots \ldots \ldots 15$

TABLE VI CANDIDATE MATERIALS

COMPARISON OF CASTINGS ON GLASS $\ldots \ldots \ldots \ldots \ldots \ldots, 15$

TABLE VII CANDIDATE MATERIALS $\ldots \ldots \ldots \ldots \ldots \ldots \ldots \ldots \ldots \ldots, 16$

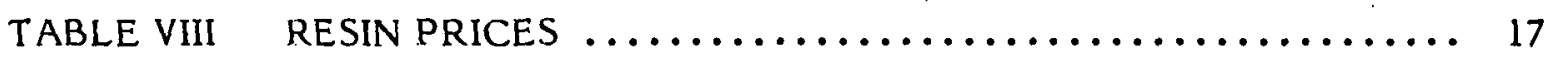

TABLE IX RESIN CAST AS A FUNCTION OF

SLAB THICKNESS $\ldots \ldots \ldots \ldots \ldots \ldots \ldots \ldots \ldots \ldots \ldots \ldots \ldots, 17$

TABLE $X \quad$ MATERIAL CANDIDATE RANIKING $\ldots \ldots \ldots \ldots \ldots \ldots \ldots, 22$

TABLE XI OPTICAL EFFICIENCY TEST RESULTS $\ldots \ldots \ldots \ldots \ldots \ldots .24$ 


\section{INTRODUCTION}

Fresnel lenses for photovoltaic applications are currently produced by either casting or compression molding acrylic plastic material. Although high optical qualities have been achieved by these methods, there are a number of construction features which might be improved. Improvement potentials include,
- Reduced cost
- Greater stiffness
- Improved abrasion resistance .
- Reduced thermal expansion and contraction

These opportunities for improvement of Fresnel lenses were recognized by RCA Laboratories who conceived and reduced to practice a laminated lens vacuum casting technique ${ }^{1}$. This work, covered under U.S. patent 4,170,616 formed the background for the study work reported herein. The objective of this development project was to further the task of establishing the feasability of producing lenses with a cost effectiveness superior to that of monolithic cast acrylic.

The low cost Fresnel lens concept is based upon the use of a glass plate to which are affixed plastic facets comprising the refracting elements of a plano-convex lens. With this arrangement the glass provides the stiffness, abrasion resistance and low thermal expansion and contraction characteristics. The plastic facets bonded to the glass surface face the target. These facets are reasonably protected from the environment.

The development aspects of this concept deal with the selection of suitable plastic faceting materials, the identification of appropriate manufacturing methods, the verification of environmental resistance, the determination of optical characteristics of the design and the measurement of cost effectiveness of the selected arrangements.

The optical design of the Fresnel lens used in this study was developed in a parallel project conducted by Swedlow, Inc. ${ }^{2}$. The design consisted of 6.7 inch square lens elements arranged in a $5 \times 5$ parquet. See Figure 1 and Table 1 . Since the indices of refraction of the materials studied were different from that of acrylic, the optical design was not optimal for these materials. The non-optimal design was, however, deemed to be satisfactory for the purpose of demonstrating the capabilities of the study materials.

Replicating tools developed in this parallel project were used in the subject study to generate the plastic faceting as applied to the glass superstrate. 


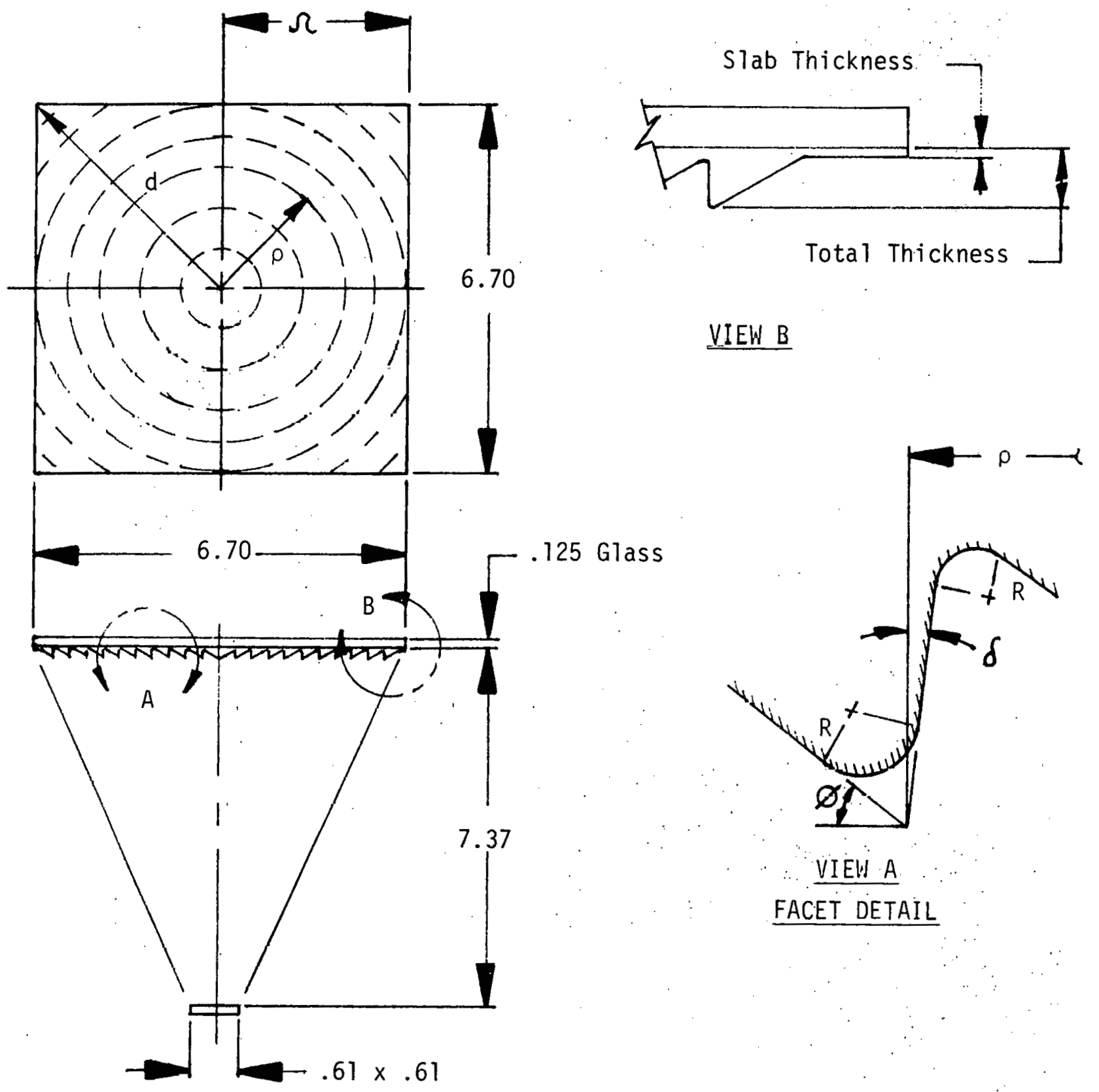

LENS ELEMENT GEOMETRY FIGURE 1 
TABLE I

CHARACTERISTICS OF LENS

\begin{tabular}{|c|c|c|c|}
\hline Solar spectrum of interest & $\lambda_{j}$ & .4 & $\mu \mathrm{m}-1.1 \mu \mathrm{m}$ \\
\hline Width of facets (tip to tip) & w & .025 & inch \\
\hline Facet draft angle & $\delta$ & 1.5 & deg. \\
\hline Index of refraction & $\eta_{D}$ & 1.486 & \\
\hline Lens-to-target distance & $\mathrm{F}$ & 7.37 & inch \\
\hline Facet tip and root radii & $\mathrm{R}$ & .0001 & inch \\
\hline Lens element half width & $\mathbf{r}$ & 3.35 & inch \\
\hline Lens element half diagonal & $d$ & 4.74 & inch \\
\hline Parquet & & $5 \times 5$ & elements \\
\hline Parquet dimension & & 34.5 & inch $\times 34.5$ inch \\
\hline Facet angle tolerance & $\Delta \phi$ & \pm 1 & $\mathrm{mr}$ \\
\hline
\end{tabular}

This geometry results in a blockage of solar ray transmission directed to the target of approximately $3.5 \%$.

$\begin{array}{lr}\text { Total lens area } & 44.89 \mathrm{in}^{2} \\ \text { Horizontal area of tip \& root radii } & .86 \mathrm{in}^{2} \\ \text { Horizontal area of draft surface } & .68 \mathrm{in}^{2} \\ \quad \text { Total blockage area } & 1.54 \mathrm{in}^{2} \\ \text { Percent Blockage }=1.54 / 44.89 & 3.44 \%\end{array}$




\section{EFFECT OF OPTICAL EFFICIENCY ON SYSTEM COST EFFECTIVENESS}

To evaluate the cost effectiveness of alternative solar energy concentrating optical elements it is necessary to consider the affect of optical efficiency on system cost. The baseline optical element for this comparative analysis is the cast acrylic Fresnel lens. These lenses have been estimated to cost about $\$ 2.50$ per square foot in 1978 dollars when production levels of a million square per year are reached ${ }^{5}$. Optical efficiency of these lenses are reported to be about $80 \%$ when evaluated over the silicon solar cell activation energy spectrum ${ }^{2}$. Clearly, if alternative lenses can be produced with comparable optical efficiencies and at a reduced lifetime cost then all is well. However, if alternative lenses are found to have lower optical efficiencies then a larger concentrator system is required in order to achieve an equal power output and costs will tend to substantially increase unless the optical element cost reduction can act as an offset.

The photovoltaic system power output per unit aperture area when using solar conentration is given by,

$$
\begin{aligned}
\text { W/A } & =I_{O} n_{B} n_{T} n_{I} n_{C} \\
\text { where, } & \text { Total power output } \\
\text { W } & =\text { Optical aperature area } \\
I_{0} & =\text { Insolation } \\
n_{B} & =\text { Tralsparent ared effi•iency } \\
n_{T} & =\text { (Considers support structure optical blockage) } \\
n_{I} & =\text { Target intercept efficiency } \\
n_{C} & =\text { Solar cell conversion efficiency }
\end{aligned}
$$

All of the efficiencies, with the exception of the cell conversion efficiency, may be lumped together for this analysis and termed the optical efficiency.

$$
n_{0}=n_{B} n_{T} \eta_{I}
$$

It is apparent that the required aperture area is inversely proportional to this optical efficiency. In comparing optical systems, given that the power output, insolation and cell conversion efficiency are held constant, the ratio of area is equal to the ratio of optical efficiencies. 


$$
\begin{aligned}
& A=\frac{1}{\eta_{0}} \cdot \frac{W}{I_{0} n_{c}} \\
& A_{2}=A_{1} \frac{\eta_{1}}{\eta_{2}}
\end{aligned}
$$

The system cost is, of course, directly proportional to the required optical aperture. System cost is generally comprised of the costs for concentration optics, silicon solar cell and assembly, array structure and tracking, assembly and testing.

$$
\text { C. }=C_{0}+C_{s}
$$

where,
$\mathrm{C}=$ Total system cost
$\mathrm{C}_{0}=$ Concentration optics cost
$\mathrm{C}_{\mathrm{S}}=$ All other system costs

Thus, for two competing systems their cost and efficiencies are directly related.

$$
c_{2}=c_{1} \frac{\eta_{b_{1}}}{\eta_{0_{2}}}
$$

For analysis purposes, it is assumed that only the concentration optics cost is variable. The relationship between the concentration optics cost and the optical efficiency for alternative systems may be derived based on the equality of total system costs.

$$
\begin{aligned}
& c_{1}=C_{0_{1}}+C_{s_{1}} \\
& c_{2}=c_{1} \frac{n_{0_{1}}}{n_{0_{2}}}=c_{o_{2}} \cdot \frac{n_{O_{1}}}{n_{0_{2}}}+c_{s_{1}} \cdot \frac{n_{O_{1}}}{n_{O_{2}}} \\
& C_{0_{2}}=C_{o_{1}}-\Delta C_{0}
\end{aligned}
$$

where,

$\Delta \mathrm{C}_{0}=$. The change in concentration optics cost between systems For $\mathrm{C}_{2}=\mathrm{C}_{1}$ then,

$$
\frac{\eta_{0_{1}}}{\eta_{o_{2}}}\left(c_{o_{1}}+c_{s_{1}}\right)-\frac{\eta_{o_{1}}}{\eta_{o_{2}}} \cdot \Delta c_{0}=c_{o_{1}}+c_{s_{1}}
$$




$$
\Delta \mathrm{C}_{0}=\left(\mathrm{C}_{0_{1}}+\mathrm{C}_{\mathrm{s}_{1}}\right) \frac{\eta_{\mathrm{o}_{1}}-\eta_{\mathrm{o}_{2}}}{\eta_{\mathrm{i}_{1}}}
$$

Estimates of the photovoltaic concentrator system costs reveal that the concentration optics comprise about $25 \%$ of the total system costs . Based on this it may be seen that a drop in optical efficiency for an alternative system of $10 \%$ requires a $40 \%$ drop in concentration optics cost in order to maintain an equality of total system cost.

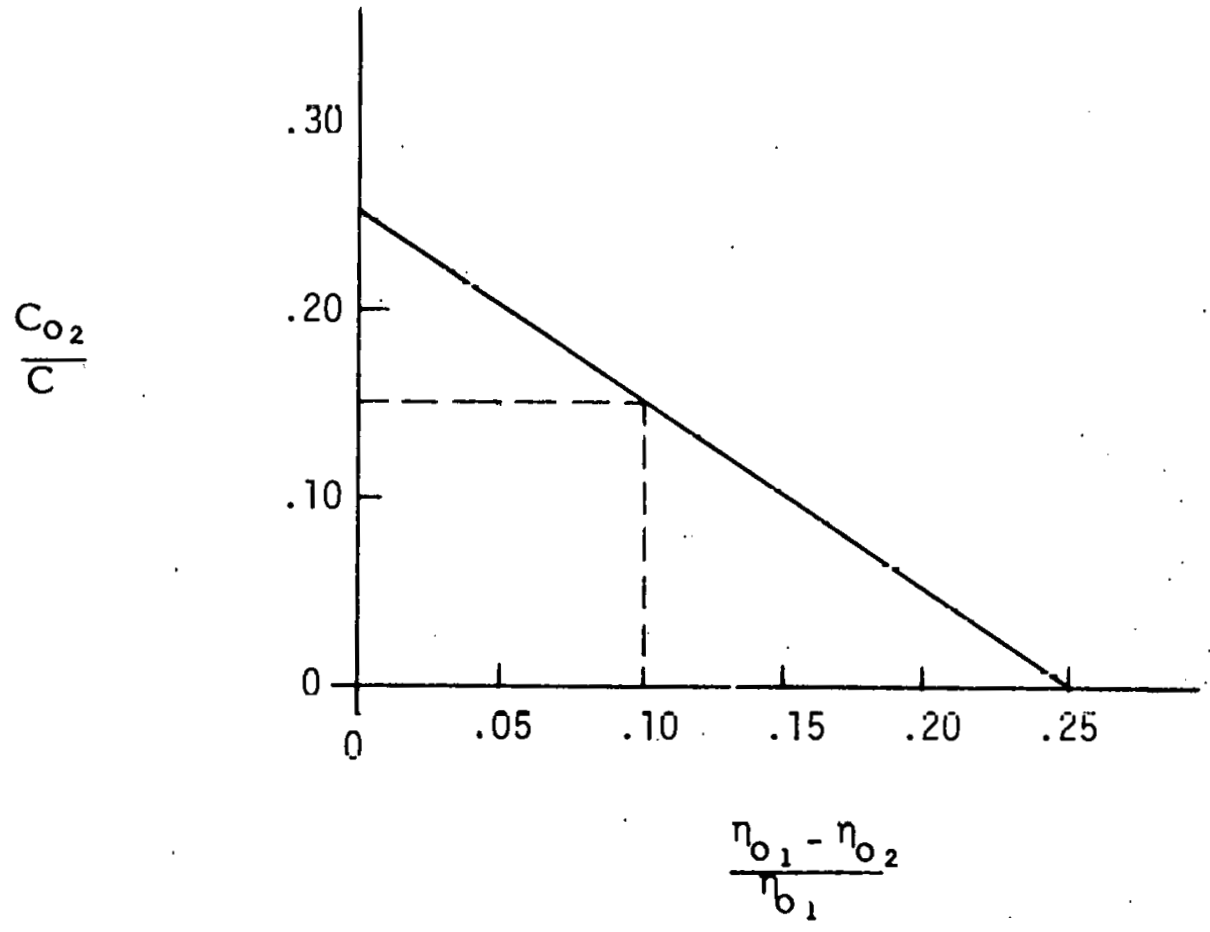

CONCENTRATOR SYSTEM COSTS VS LENS EFFICIENCY

FIGURE 2

Thus, relative optical efficiency is an important consideration in the evaluation of alternative optical elements in solar concentrators. Of course, the analysis just described assumes equal product lives. 


\section{GLASS SELECTION}

The criteria which must be considered when selecting the glass superstrate include,

- Resistance to thermal cycling stresses when bonded to plastic lens elements. Temperature extremes are from $-22^{\circ} \mathrm{F}$ to $+122^{\circ} \mathrm{F}$.

- Resistance to the impact of a 1.0 inch diameter hail impact at $55 \mathrm{mph}$ velocity.

- Light transmission in the wavelength range from $0.4 \mathrm{microns}$ to 1.1 microns.

- Minimum deflection when subjected to $30 \mathrm{mph}$ wind loading.

- Survival under a $90 \mathrm{mph}$ wind loading.

- Minimum cost.

Four types of glass were considered; ordinary soda lime, low iron soda lime, borosilicate and aluminosilicate. Ordinary soda lime glass is the most common, is low cost, and is readily available. The problem with this glass is that it contains iron which limits its transmission of solar energy. Low iron soda lime glass offers an alternative. Schott Glass Co. of Germany produces a B-270 iron free crown glass which has excellent light transmission but is very expensive. A source of inexpensive low iron glass is Jeannette Corporation, 106 Sailer Street, Jeannette, PA. 15644, 412-523-8501, Solaclean Type A or B. These glasses are much lower in cost than Schott B-270. Transmission is down about 2\%. AFG also produces a low iron soda lime called Solatex but this glass has a textured surface which renders it unsuitable for this application. Borosi!.icate glass also has excellent light transmission but only Corning Glass Works produces a material suitable for solar application and availability is poor while the cost is high. The best type of glass, sodium aluminosilicate, is the least available for solar applications and is about as expensive as the borosilicate.

Cost and light transmission data obtained for these glasses are shown in Table II. 
TABLE II

COST AND LIGHT TRANSMITTANCE DATA

FOR

\section{CANDIDATE GLASS TYPES}

\begin{tabular}{|c|c|c|c|c|c|c|c|c|}
\hline \multirow[b]{2}{*}{ Glass Type } & \multirow[b]{2}{*}{ Trade Name } & \multirow[b]{2}{*}{ Manufacturer } & \multirow{2}{*}{$\begin{array}{c}\text { Averaye Pervellace } \\
\text { Light Iransmission in } \\
\text { Wavelength Range } 400 \mathrm{~mm} \text { to } \\
1100 \mathrm{~mm} \text { for } 3 / 16^{\prime \prime} \text { glass } \\
\end{array}$} & \multicolumn{5}{|c|}{ 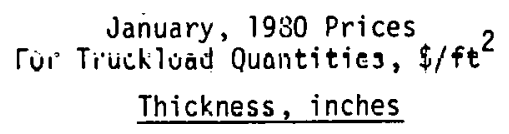 } \\
\hline & & & & $1 / 8$ & $5 / 32$ & $3 / 16$ & $7 / 32$ & $1 / 4$ \\
\hline $\begin{array}{l}\text { Soda-Lime, } \\
\text { Tempered }\end{array}$ & $\begin{array}{l}\text { Soda-Lime, } \\
\text { Tempered }\end{array}$ & $\begin{array}{l}\text { Guardian } \\
\text { Glass }\end{array}$ & 82 & 0.65 & 0.68 & 0.80 & & 1.10 \\
\hline $\begin{array}{l}\text { Soda-Lime, } \\
\text { Untempered }\end{array}$ & Soda-Lime & PPG & 82 & 0.48 & & 0.84 & & 0.88 \\
\hline $\begin{array}{l}\text { Low-Iron } \\
\text { Soda-Lime, } \\
\text { Tempered }\end{array}$ & Solatex & AFG & 89 & 0.61 & 0.72 & & & 0.83 \\
\hline Borosilicate & Pyrex & $\begin{array}{l}\text { Corning } \\
\text { GTass }\end{array}$ & 92 & 2.00 & & & $\begin{array}{l}4.25 \\
.\end{array}$ & \\
\hline $\begin{array}{l}\text { Iron-free } \\
\text { Crown glass, } \\
\text { Polished, } \\
\text { Untempered }\end{array}$ & $B-270$ & $\begin{array}{l}\text { Schott } \\
\text { Optical Glass }\end{array}$ & 92 & & & $19.70^{\prime}$ & & \\
\hline $\begin{array}{l}\text { Low-Iron } \\
\text { Soda- } \\
\text { Lille }\end{array}$ & $\begin{array}{l}\text { Solaclear } \\
\text { Type A } \\
\text { Type B }\end{array}$ & Jeannette & $\begin{array}{l}89 \\
89\end{array}$ & $\begin{array}{r}1.16 \\
.91\end{array}$ & & & & \\
\hline
\end{tabular}

(i) It has been reported that this glass may be obtained for about $\$ 1.78 / \mathrm{ft}^{2}$ in large quantities. 
Based just on the cost and availability factors, the only viable glass type which can be currently considered is the soda lime type.

Hail impact testing was conducted on tempered soda lime glass and acrylic as a part of this project ${ }^{3}$. Under multiple impacts of a 1.0 inch diameter hail stone, the velocity at which the glass and acrylic would fail was determined. Results are,

\section{Material \\ $\underline{\left(1 / 8^{\prime \prime} \text { thick }\right)}$}

Acrylic

Tempered Soda Line Glass

\section{Failure Velocity}

$150 \mathrm{ft} / \mathrm{sec}(102 \mathrm{mph})$

$110 \mathrm{ft} / \mathrm{sec}(75 \mathrm{mph})$

Both of these materials were found to survive the specified $55 \mathrm{mph}$ hail impact condition.

The modulus of elasticity of glass is $1 \times 10^{7}$ psi whereas acrylic is $0.45 \times 10^{6}$, thus glass is over 20 times stiffer in bending than acrylic of equal dimensions. Fresnel lenses made of acrylic and used in solar applications have normally been about $1 / 8$ inch to $3 / 16$ inch thick. The use of $1 / 8$ inch thick glass with about 10 to 20 times the stiffness of existing lenses therefore, seems appropriate.

The maximum stress and deflection of a $1 / 8$ inch thick glass 34.5 inches by 34.5 inches square are shown in Figure 3 as a function of wind velocity for the case where the wind is acting normal to the plate. Small deflection theory is used and as such, for wind conditions above $30 \mathrm{mph}$ the stresses are approximately correct but the deflection is greater than would actually occur.

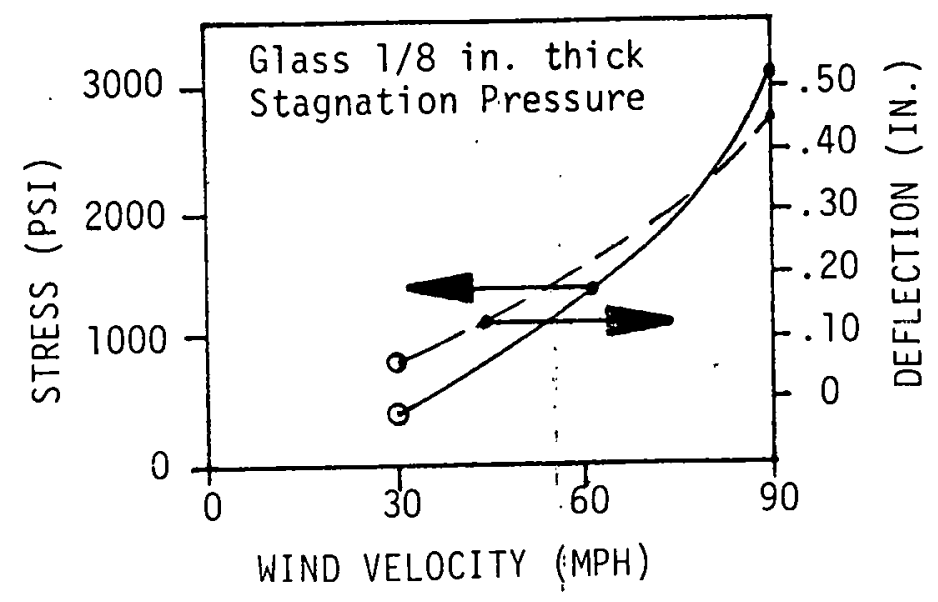

GLASS STRESSES AND DEFLECTION VS NORMAL WIND VELOCITY FOR A 34.5 INCHES SQUARE PLATE FIGURE 3 
Based on a glass ultimate strength of 10,000 psi under short term or momentary loading it is estimated that a periodic loading, such as developed by wind, would result in an allowable strength of about 3,000 psi. This allowable is very close to the expected stress under worst case wind conditions. Thus, it appears that the $1 / 8$ inch thick glass is structurally appropriate.

The glass used in this study was $1 / 8$ inch thick soda lime and although the light transmittance is not as high as one would like its cost and availability are appropriate in the near term. 


\section{FACET MATERIAL SELECTION CONSIDERATIONS}

Selection of the proper facet material involves optical, mechanical, process and cost considerations in addition to providing for environmental survivability. These points of design concern will be briefly described prior to the presentation of study results.

Maximizing specular transmission of solar radiation to the photovoltaic target is fundamental to lens design. High lens transmission results in the need for less concentrators and, thus, reduced system cost. The transmission within the selected radiation band must be high and specular. Outside this pass band the attenuation should be high in order to minimize radiant heating of the photovoltaic device. Stability of the optical focus is dependent upon changes in index of refraction due to temperature and stress variations. Minimizing these effects is desirable. To maximize the optical concentration it is also desirable to obtain a material with the minimum variation in index of refraction with wavelength. Additionally, to maintain this specular transmission the lens material must be environmentally stable. Effects on optical properties of the lens material should be minimally affected by hydrolysis and oxidation mechanisms and resistant to ultra-violet radiation deterioration.

Dissimilar coefficients of expansion will exist between the facet material and the glass superstrate. As such, adhesion of the facets to the glass, stress induced deformations of the weaker facet material and general bending of the lens may result in mechanical failures and/or reduced optical performance. The modulus of elasticity of the facet material, the thickness of this plastic, its coefficient of thermal expansion and its ability to adhere to the glass are important variables in this material selection.

The selected process for applying the facet material to the glass must result in a void and inclusion free faceting while producing a high quality replication of the lens mold surface. Shrinkage of the plastie material during cure, if present, should be minimized. And, of course, the process must be low cost in the production volumes anticipated for solar concentrators.

Functionally the lens facets must not optically degrade over a life of some 20 years when exposed to the imposed stresses of its environment. Moisture's effect on the bond of facets to the glass is of critical concern. Also, the changes in optical properties such as coloration, becoming diffuse in optical transmission, and changes in geometry must be obviated.

These concerns, therefore, constitute the background against which alternative materials are to be judged with respect to suitability as a facet material in this solar concentration application. It was not possible within the scope of this program to quantify all of these characteristics for competing materials. These characteristics were, however, used as subjective criteria in defining reasonable material candidates. 


\section{FACET MATERIAL SELECTION}

Five general criteria were used to judge the general suitability of polymers for facet material consideration. These criteria included,

- Solar energy transparency

- Flexability or extensional stiffness

- Weatherability

- Processability

1) Pridis

Only those polymeric materials which were currently transparent, as opposed to those materials which could potentially be made transparent, were considered for evaluation.

Flexible plastics were assumed to be the preferred material when bonding to glass. This assumption was based on the consideration of the mismatch in coefficients of thermal expansion and the effect of this mismatch on material and bond joint survivability. The difference in coefficients is about one order of magnitude and can result in significant bond shear stresses and polymer deformations which are cyclic in nature. For screening purposes, the material hardness range of 30 to 70 Shore A was selected while the tensile modulus of elasticity range of 100 to 1800 psi was assumed.

Only material types which possessed an acceptable combination of properties such as ultra-violet light stability, oxygen and ozone resistance, and moisture resistance were considered. A judgment was made as to the expected life of these materials relative to the life of as-cast acrylic. Ihis factor is important in relative cost considerations.

Processability of materials was not initially used in the material selection screening. Materials. which were capable of being injection molded would be preferred in a long term sense. However, for this lab study, material which would be readily fabricated via casting techniques were chosen.

Material candidates were not initially screened out on the basis of price due to the small quantity of material which would be used for the facets. Certain materials, however, are of substantial price and coupled with processing costs may result in their exclusion.

The general selection of candidate polymeric material types was based on the screening noted above. This screening is summarized in Table III and reflects the passing of thermoplastics, thermosets, and elastomers through progresive screens of transparency, flexibility and weatherability. 
TABLE III

MATERIAL GENERAL SCREENING

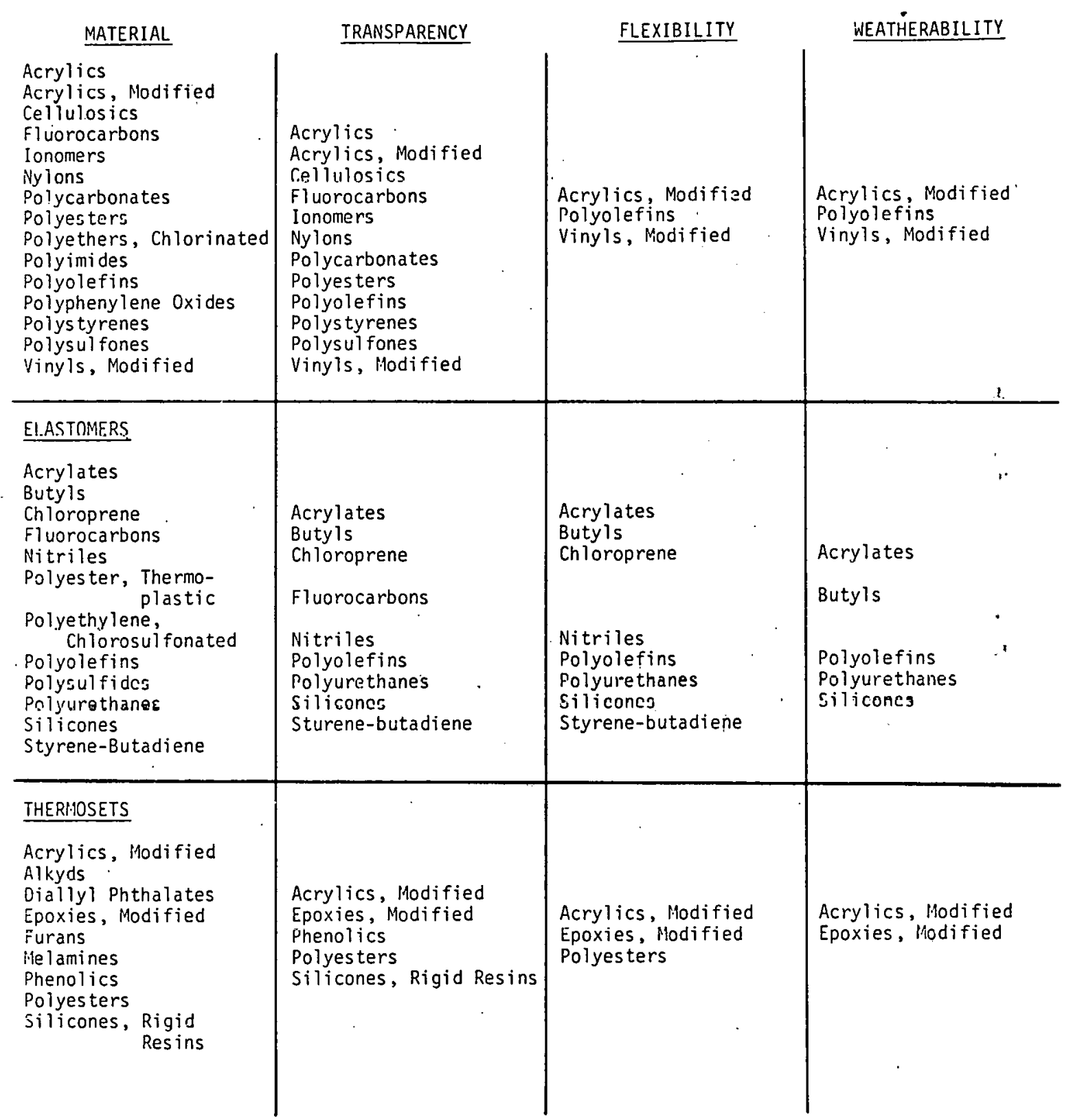


Material family candidates which were included in further analysis, based on this screening, may be seen in Table IV.

TABLE IV

GENERAL CANDIDATES

Thermoplastics

Acrylics - Modified

Olefins

Vinyls - Modified

Thermosets

Acrylics - Modified

Epoxies - Modified

Elastomers

Acrylates

Buryls

Olefins

Silicones

Urethanes

Manufacturers and suppliers were contacted in or der to obtain recommendations of transparent, flexible, and weatherable candidates within each material category. Due to budget constraints the evaluation was restricted to liquid castable resins only. Certainly, the other materials would warrant evaluation if the outcome of the general evaluation of the concept should prove favorable.

The material categories which were selected for experimentation were, therefore; modified epoxies, silicones, and urethanes. Seven resin systems were obtained for initial screening. These are set for th in Table V. 


\section{TABLE V \\ CANDIDATE MATERIAL FOR EVALUATION}

\begin{tabular}{|c|c|c|c|}
\hline Trade Name & Manufacturer/Supplier & Material Category & Material Type \\
\hline ND- 1100 & Cal Polymers & Thermoset Urethane & Aliphatic Polyether \\
\hline Urelane $5754 \mathrm{~A} / \mathrm{B}$ & M \& $T$ Chemicals & Thermoset Urethane & Aliphatic Polyether \\
\hline $55-6640$ & Swedlow & Thermoplastic Urethane & Proprietary \\
\hline RTV-670 & General Electric & Thermoset Silicone & Dimethylsiloxane \\
\hline SS-5272V(HT) & Swe.tl nw & Thermoset Silicone & Proprietary \\
\hline DER $332 / 732$ & Dow Chemical & Thermoset Epoxy & $\begin{array}{l}\text { Modified diglycidyl } \\
\text { ether of bisphenol A }\end{array}$ \\
\hline $\begin{array}{l}\text { ERL-4221/NIAX } \\
\text { Polyol LHT-240 }\end{array}$ & Union Carbide & Thermoset Epoxy & Cycloaliphatic \\
\hline
\end{tabular}

These materials were cast onto soda lime plate glass in thin sections and compared in terms of ease of casting, appearance, thermal cycling stability, and adhesion to the glass. The thermal cycling test consisted of ten cycles between $-40^{\circ} \mathrm{F}$ and $+140^{\circ} \mathrm{F}$. A summary of the results of this evaluation is shown in Table VI.

\section{TABLE VI \\ CANDIDATE MATERIALS \\ COMPARISON OF CASTINGS ON GLASS}

\begin{tabular}{|c|c|c|c|c|}
\hline Irade Name & Ease of Casting & Appearance & Thermal Cycling Stability & Adhesion to Glass \\
\hline NO- 1100 & Good & Water-white & Fair & Good \\
\hline Urelane $5754 A / B$ & Poor & $\begin{array}{l}\text { Water-white } \\
\text { Many bubbles }\end{array}$ & Good & Good \\
\hline SS- 6640 & Good & $\begin{array}{l}\text { Water-white, few } \\
\text { bubbles, tacky surface }\end{array}$ & Good & Good \\
\hline RTV -670 & Good & Wa teer-whi t.e & Good & Poor \\
\hline SS-5272Y(HT) & Good & Water-white & Good & Good \\
\hline DER $332 / 732$ & Good & Yellow & Poor & Good \\
\hline $\begin{array}{l}\text { ERL-4221/NIAX } \\
\text { Pnlyni I.HT-2A0 }\end{array}$ & Good & Light Yellow & Poor & Good \\
\hline
\end{tabular}


ND1 100 had good optical qualities and adhered well to glass. Urelane 5754 had a very short pot life which did not allow for adequate degassing: castings made from it had many bubbles. SS-6640 had a few bubbles, a tacky surface, and adhered well to glass. Both the silicones were cast using different primers. RTV-670 castings were easily pulled off the glass by hand; SS-5272Y(HT) adhered well both with and without primers. Both the epoxy castings had a yellow color but adhered well to glass. A thermal cycling test of ten cycles between $-40^{\circ} \mathrm{F}$ and $140^{\circ} \mathrm{F}$ resulted in the low temperature cracking of DER $332 / 732$ and the partial delamination of ERL-4221. The other candidates showned no apparent changes. As a result of this analysis, both epoxy candidates and Urelane 5754 were eliminated from further consideration.

The materials which then remained in the evaluation were samples of urethanes and silionone.

\section{TABLE VII}

\section{CANDIDATE MATERIALS}

\section{Trade Name}

ND 1100

SS-6640

RTV -670

SS-5272Y(HT)
Manufacturer/Supplier

Cal Polymers

Swedlow

General Electric

Swedlow

\section{Class}

Thermoset Urethane

Thermoplastic Urethane

Thermoset Silicone

Thermoset Silicone

Cal Polymers urethanes are room-temperature cured, two-part systems. ND 1100 partially delaminated from the glass when subjected to a thermal cycling of 10 cycles between $-40^{\circ} \mathrm{F}$ and $140^{\circ} \mathrm{F}$; as such, a more flexible Cal Polymers urethane with a hardness closer to that of silicones was selected for laminated lens process development work. Adhesion to glass was fairly good, although the urethane could be pulled off the glass by hand with some effort.

The SS-6640 candidate, also a urethane, is press-cured at elevated temperature. It has a very short pot life which makes bubble removal a problem. The primary difficulty with this material is that it partially adheres to the flexible molds which were used. This material was dropped from further consideration due to these problems and budget constraints.

The adhesion of RTV -670 , a silicone, to glass is not as good as ND 2300 even with the use of the various primers.

SS-5272Y(HT) is a heat-cured silicone with excellent adhesion to glass. It did, however, present difficulties in terms of release from a flexible mold and bubble removal due to its very high viscosity ( 3000 poise). The flexible molds tried included RTV -664 , RTV -60 , the silicone itself used as a mold, and polypropylene. 
The costs of these candidate materials including the SS-6640, is shown in Table VIII and IX.

TABLE VIII

\section{RESIN PRICES}

Candidate

ND 2300

SS-6640

RTV-670

SS-5272Y(HT)
Price, $\$ / \mathrm{lb}$ as of December 1979

3.50

1.50

14.00

17.40
Density Lb/Gal.

8.0

8.0

12.0

110.6

139.2

TABLE IX

\section{RESIN COST AS A FUNCTION OF SLAB THICKNESS(1)}

\begin{tabular}{|c|c|c|c|c|c|}
\hline $\begin{array}{c}\text { Resin Slab Thickness, } \\
\text { Mils }\end{array}$ & $\begin{array}{l}\text { Volume of Facets } \\
\text { and Slab, } \operatorname{In}^{3} / \mathrm{ft}^{2}\end{array}$ & ND2300 & $\begin{array}{r}\text { Resin } \\
\text { Can } \\
\text { SS-6640 }\end{array}$ & $\begin{array}{l}\text { ost, } \$ / \mathrm{ft}^{2} \\
\text { didate } \\
\text { RTV-670 }\end{array}$ & $\mathrm{SS} 5272 \mathrm{Y}(\mathrm{HT})$ \\
\hline 0 & 0.98 & 0.12 & 0.05 & 0.47 & 0.60 \\
\hline 20 & 3.87 & 0.47 & 0.20 & 1.84 & 2.34 \\
\hline 40. & 6.76 & 0.82 & 0.35 & 3.21 & 4.09 \\
\hline 60 & 9.65 & 1.17 & 0.50 & 4.58 & 5.84 \\
\hline 80 & 12.54 & 1.52 & 0.65 & 5.95 & 7.59 \\
\hline 100 & 15.43 & 1.87 & 0.80 & 7.32 & 9.34 \\
\hline
\end{tabular}

(1) See Figure 1 for a description of slab thickness

Testing of the three remaining candidate materials were conducted and the results of that testing are reported in the following sections of this report. 


\section{GENERAL TESTING}

A series of tests were performed on fabricated single lenses. The objective of these tests was to define the relative performance of the candidate materials both before and after weathering and to rank candidates on the basis of weatherability. The following tests were done on single lenses and plane sections:
- Accelerated UV-Aging
- Water Absorption
- Weatherometer
Q Optical Performance
- Light Transmittance and Haze
- Peel Strength
- Thermal Cycling
- Hail Impact

The optical performances of the lenses and the light transmittance, haze, and peel strengths of the plane sections were determined before and after the accelerated UV-aging, water absorption, and weatherometer tests. The thermal cycling test was done on lenses; the hail impact test was done on array-size tempered glass only.

The following polymer candidates were tested:

Trade Name

RTV -670

SS-5272Y(HT)

ND-2300 $\underline{\text { Class }}$

Thermoset Silicone

Thermuset Silicone

Thermoset Urethane

Results of this testing are reported in Reference 3 and highlights of this testing are presented below.

\section{Accelerated UV-Aging}

The accelerated UV aging tests were conducted using a UV tower designed by E.I. DuPont de Nemours \& Company. This apparatus serves as a tool for obtaining rapid evaluations of the relative instabilities of polymer materials upon exposure to UV light. The UV tower approximates natural solar energy in the ultraviolet region of the spectrum below wavelengths of 360 millimicrons. The illumination peaks at 320 
millimicrons with an intensity which is about three times that of natural noon sunlight in June. Radiation in the UV tower comes from eight 20 -watt fluorescent vertically-mounted sunlamps.

The exposure period was 336 hours. DuPont found that in their use of the UV tower on specific materials, 336 hours of exposure is equivalent to approximately five years of exposure in the Florida sun. Due to known variations in correlations of artificial exposure to solar exposure with various materials, the equivalency is a rough approximation at best.

Of the silicone candidates, only one SS-5272Y(HT) specimen exhibited a slight haze after the two-week UV tower exposure. RTV-670 specimens were unchanged. All of the ND-2300 specimens turned amber and became very sticky, apparently not stable under these test conditions.

\section{Water Absorption}

Water absorption tests were conducted in accordance with ASTM Standard Method D570-63. Specimens were dried in an oven for 24 hours at $50^{\circ} \mathrm{C}$, cooled in a desiccator, and immediately weighed. These conditioned specimens were then placed in a container of distilled water maintained at $23^{\circ} \mathrm{C}$, resting on edge, in order to determine the total water absorbed when substantially saturated.

After 24 hours, the specimens were removed from the water, all surface water wiped off with a dry cloth, weighed immediately, and then replaced in the water. The weighings were repeated at the end of the first week and every two weeks thereafter until the increase in weight per two-week period, as shown by three consecutive weighings, averaged less than one percent of the total increase in weight, or $5 \mathrm{mg}$, whichever was greater. The specimens were then considered to be substantially saturated. The difference between the substantially saturated weight and the dry weight was considered as the water absorbed.

The average weight percent of water absorbed and soluble matter lost based on the specimen weights are as follows:

Candidate

Monolithic Acrylic

RTV -670

SS-5272Y(HT)

ND-2300
Wt. \% Water Absorbed

0.07

0.62
Wt. \% Soluble Matter Lost

0.07

0.02

0.05

0.04

The acrylic lens did not change in appearance. One RTV-670 specimen was slightly hazy and yellow; two did not change. Two SS-5272Y(HT) specimens were hazy with one unchanged. Four of six ND-2300 specimens delaminated; the other two were unchanged. All candidates are apparently affected by the test conditions, RTV-670 being most stable. 


\section{Weatherometer}

The weatherometer tests were conducted per Procedure A of ASTM D256-70. The effects of accelerated weathering on the specimens were determined using the following Atlas equipment: model 65/DMC-R weatherometer; model $\mathrm{RM}-5 \mathrm{~A}$ conversion Xenon unit; model CS-5 Xenon ARC lamp cooling water circulator. The temperature was maintained at $63^{\circ} \pm 2^{\circ} \mathrm{C}$. The cycle consisted of 102 minutes of light followed by 18 minutes of light combined with demineralized water spray. The power input to the xenon-ARC lamp was raised from 5000 watts to 7000 watts over a 1500 hour lamp life in order to provide a constant irradiance. The test specimens were exposed for 2000 hours.

All the ND-2300 specimens, both the 2:1 and 3:2 ingredients ratio, dissolved in the weatherometer and flowed off the glass within the first 1000 hours. All the silicone lenses survived the 2000 hours of testing without discoloration or loss of adhesion to glass. The monolithic acrylic lenses remained unchanged in appearance after the weatherometer exposure.

\section{Optical Performance}

Lens efficiencies and energy distributions across the target were obtained for the surviving lenses in the testing program. Of the ND-2300 lenses, the water absorption specimen delaminated in some areas resulting in a $39 \%$ lens efficiency after weathering. The weatherometer sample dissolved completely. The UV-aging specimen efficiency dropped from 64 to $56 \%$. The silicone lens efficiencies change less than $6 \%$ for all weathering tests. Monolithic acrylic lens efficiencies showed increased efficiencies after weathering which cannot be explained. The efficiencies obtained from the lens analyzer are suspect due to variations up to $10 \%$ in the values of control specimens. The values for the most weatherable candidates, silicones, are therefore too close to rank on this basis.

\section{Light Transmittänce and Häzè}

Light transmittance and haze values for the candidate materials before and after weathering are shown in Reference 3. These results were then categorized in terms of unweathered. and weathered specimens for each weathering test. The change in these values due to weathering were averaged for each candidate and shown with the data sheet.

Urethane ND-2300 samples dissolved in the UV-aging and weatherometer tests. The water absorption test sample experienced a drop of $1.7 \%$ in light transmittance and a $3.4 \%$ rise in haze. The average rise in light transmittance and drop in haze for SS-5272Y(HT) were 2.7 and $9.5 \%$ respectively. RTV-670 had values of 2.3 and $11.0 \%$. The relatively high haze values of the silicones are due to lint and dust pickup. Silicones require a filtered environment in order to protect against this pickup. Transmittance values for all candidates are very close.

\section{Peel Strength}

Peel strengths were attempted for all specimens. The ND-2300 samples averaged 34 seconds per inch using a $11 / 2$ pound weight. All silicone SS-5272Y(HT) 
specimens failed cohesively at $61 / 2$ pounds. RTV -670 was too brittle and broke in all cases upon the application of the slightest load. The material ranking in terms of adhesion to glass would be SS-5372Y(HT) (best), ND-2300 (middle), and RTV-670 (worst).

\section{Thermal Cycling}

The thermal cycling test consisted of 434 cycles between $+120^{\circ} \mathrm{F}$ and $-22^{\circ} \mathrm{F}$. Cycle time was about 2 hours composed of 20 minute temperature transistions, 30 minute temperature stabilizations, and 5 minute minimum specimen temperature dwells at each temperature extreme. All six laminated lenses showed no evidence of blistering, peeling, cracking, discoloration, or other degradation after the test.

\section{Hail Impact}

The hail impact test was conducted on $1 / 8$ inch soda lime tempered float glass panels $341 / 2 \times 341 / 2$ inches square. Hail stones were 1.0 inch in diameter. Terminal velocity of this size of hail stone is about 55 miles per hour and this was considered to be the minimum acceptable failure velocity. A range of velocities were tested, however. The 1/8 inch glass, the lowest caliper selected for impact testing, survived all shots and was therefore selected for use in the final single lens.

\section{Material Candidate Selection}

Table $X$ contains a weatherability ranking of material candidates based on the results of the UV-aging, water absorption, weatherometer, and thermal cycling tests. Optical performance, light transmittance, haze, and peel strength test results are all reflected in the results of the other tests. The hail impact test results do not contribute to the weatherability ranking but merely dictate the glass thickness to use in final single lenses.

Rank factors of 1, 2, and 3 (low to high) were assigned to each candidate for each of the four tests. Each test was weighted according to its relative affect on life cycle performance. The product of a rank factor and a weight yielded a score for each test-candidate combination. The total weighted score for each candidate was then determined. Silicone candidates were very close and ranked almost twice as highly as the urethane candidate. RTV-670 is selected as the final candidate due to its much shorter cure cycle time and ease of processing. 
TABLE $X$

\section{MATERIAL CANDIDATES RANKING}

\begin{tabular}{|c|c|c|}
\hline TEST & CANDIDATE & RANK: \\
\hline \multirow[t]{3}{*}{ UV Aging } & No.-23!!! & 1 \\
\hline & $\varepsilon \varepsilon 6373 \mathrm{Y}(\mathrm{HT})$ & 2 \\
\hline & RTV- 670 & 3 \\
\hline \multirow[t]{3}{*}{ Water Absorption } & ND-2300 & 1 \\
\hline & $S S-5272 Y(H T)$ & 3 \\
\hline & RTV -670 & 3 \\
\hline \multirow[t]{3}{*}{ Wea the rometer } & ND-2300 & 1 \\
\hline & $S S-5272 Y(H T)$ & 3 \\
\hline & RTV -670 & 3 \\
\hline \multirow[t]{3}{*}{ Thermal Cycling } & $N D-2300$ & 3. \\
\hline & SS-5272Y(HT) & 3 \\
\hline & RTV -670 & 3 \\
\hline
\end{tabular}

WEIGHT

$02 n$

ก. $2 n$

0.20

0.20

0.20

0.20

0.30

0.30

0.30

0.30

0.30

0.30

- Pank fartore range from a low of 1 to a high of 3 .

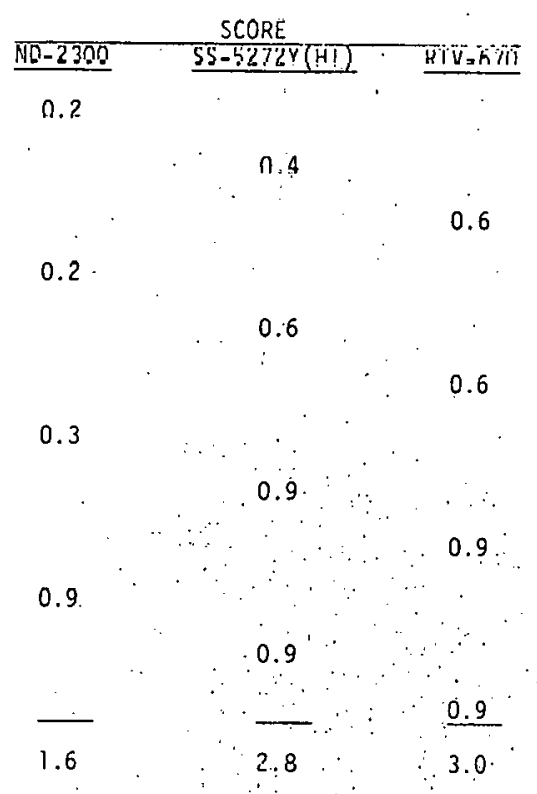




\section{OPTICAL TESTING}

The theoretical efficiency of this lens design, considering the wavelength range of $.4 \mu \mathrm{m} \geq \lambda \geq 1.1 \mu \mathrm{m}$, is estimated to be $83.5 \%$ excluding the effect of lens support losses.

\begin{tabular}{|c|c|c|}
\hline o & $\begin{array}{l}\text { Combined reflection and absorbtion } \\
\text { losses }\end{array}$ & nT \\
\hline o & $\begin{array}{l}\text { Blockage due to facet root and } \\
\text { peak radii and draft angle }\end{array}$ & $n_{B}$ \\
\hline 0 & $\begin{array}{l}\text { Scattering losses due to } \\
\text { surface roughness and di- } \\
\text { ffraction }\end{array}$ & ns \\
\hline 0 & Target intercept losses & $\eta_{I}$ \\
\hline
\end{tabular}

When these individual lenses are assembled into a $5 \times 5$ parquet and peripheral support is provided the blockage losses due to this support are about $5.7 \%$ ( $n_{B S}=$ .943) resulting in an overall efficiency of $78.7 \%$.

$$
\eta=\eta_{0} n_{B S}=.787
$$

Actual efficiencies would be expected to be lower than this due to manufactuing induced defects.

Testing of individual lens elements made of monolithic acrylic were conducted as a part of another contract (See Reference 2). The test methods used resulted in a considerable scatter in the measured efficiencies but it appears that the efficiency is about $80 \%$. General results of that testing are shown below.

$\begin{array}{lll}\text { Test Agency } & \text { Test Method } & \text { Efficiency - no } \\ \text { Optical Science Group } & \text { Laser \& Cell } & .800 / .855 \\ \text { Sandia } & \begin{array}{l}\text { Sunlight \& Cell } \\ \text { Lens Analyzer }\end{array} & .810 / .835 \\ \text { Swedlow } & \text { Lens Analyzer } & .726 / .789 \\ & & .753 / .801\end{array}$

The measurements of optical efficiencies of the glass-plastic lenses made as a part of this project used the Swedlow lens analyzer method. Data which was obtained was quite scattered and anomalies occured which could not be explained. The data is summarized in Table XI. 
TABLE XI

OPTICAL EFFICIENCY TEST RESULTS

\begin{tabular}{|c|c|c|c|c|}
\hline $\begin{array}{l}\text { Facet Material } \\
\text { (Soda Lime Glass } \\
\text { Superstrate) }\end{array}$ & $\begin{array}{c}\text { Original } \\
\text { Sample }\end{array}$ & $\begin{array}{l}\text { Weathered } \\
\text { Sample }\end{array}$ & $\begin{array}{c}\text { Water } \\
\text { Exposed } \\
\text { Sample } \\
\end{array}$ & $\begin{array}{l}\text { UV Exposed } \\
\text { Sample }\end{array}$ \\
\hline ND-2300 & $\begin{array}{l}63.8 \\
63.8 \\
57.7 \\
63.8 \\
63.8\end{array}$ & $\begin{array}{l}\text { Fail } \\
\text { Fail } \\
\text { Fail }\end{array}$ & 38.7 & 56.1 \\
\hline $55-5272$ & $\begin{array}{l}57.7 \\
57.7 \\
57.7\end{array}$ & 80.7 & 54.4 & 62.5 \\
\hline RTV -670 & $\begin{array}{l}59.0 \\
59.0 \\
59.0 \\
59.0\end{array}$ & $\begin{array}{l}57 . \overline{5} \\
58.0\end{array}$ & 55.5 & 53.7 \\
\hline All Acrylic & $\begin{array}{l}68.5 \\
60.4\end{array}$ & 77.1 & $60.4 / 68.0$ & \\
\hline
\end{tabular}

\begin{abstract}
About the only things which can be concluded from this testing are that the glass plastic lenses had optical efficiencies approximately $10 \%$ less than monolithic acrylic and that water exposure of the urethane impairs the light transmission. These effects would be expected and the use of iron free glass, rather than the soda lime glass which was used, would greatly improve the transmittance of the romposite lens.
\end{abstract}




\section{LENS FABRICATION}

Tooling options for casting polymeric facets on glass included: (1) nickel electroform; (2) flexible tools; (3) tooling design changes. Initial attempts at using a nickel electroform all resulted in failure to separate the casting from the tool without destroying the lens. This was due to the adhesion of the polymer to nickel and resulted in the two rigid substrates to be locked together by the intricate facet geometry. Release agents were not used as it was anticipated that this would create additional problems with reduced lens efficiency and tool cleaning labor. Certain flexible tools offered the mold-release characteristics required in urethane and sillicone castings as well as the flexibility needed to subsequently peel off the tool from the glass-polymer laminate. Both silicone and polypropylene molds were used as flexible tool candidates.

Potential tooling design changes for better release included: (1) shallower facets; (2) greater draft angle; (3) ejector pins. These options were not exercised due to project scope limitations.

Figure 4 depicts the process scheme developed for fabricating a glass-polymer laminated Fresnel lens. The glass surface was cleaned until a water-break free surface was attained, dried, flow-coated with the appropriate primer, and allowed to dry. The two-part resins were weighed out, mixed by hand to homogeneity, and then vacuum degassed to remove air entrained during mixing. 


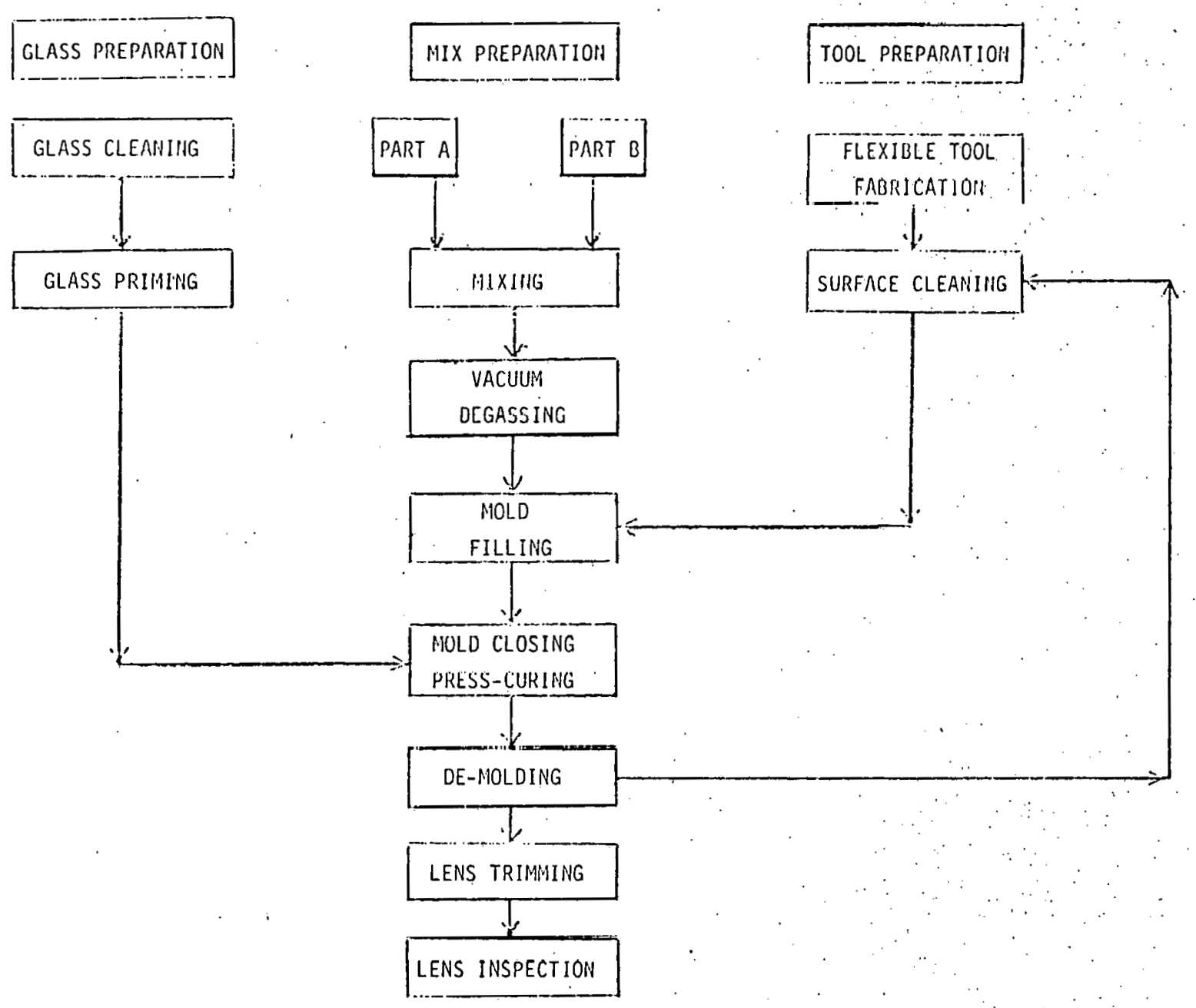

FIGURE 4

PRESS-CURED LAMINATED LENS PROCESS SCHEME 
Silicone and polypropylene molds were made from nickel electroforms. Urethane candidates released from both tooling materials whereas silicones released from polypropylene only.

General Electric's silicone RTV-664, designed for urethane castings, is a roomtemperature overnight-cured mold making material. Molds made from nickel electroforms had excellent facet definition.

Polypropylene molds were made by pressing heated polypropylene sheet onto a nickel electroform. The design parameters for maximizing the mold quality were as follows: forming temperature and pressure; cooling rate; de-mold temperature. The forming temperature was set at the $334^{\circ} \mathrm{F}$ crystalline melting temperature of polypropylene. A forming pressure of 400 psig was adequate. Too low a pressure yielded poorly-defined facets. Cooling rate affected the degree of warpage in the part as expected. Warpage was minimized by simply turning off the heat and allowing the part to cool by natural convection. A de-mold temperature of $260^{\circ} \mathrm{F}$ was selected. Too low a de-mold temperature resulted in facet deformation due to the different coefficients of thermal expansion of the nickel electroform and polypropylene. Higher de-mold temperatures proved impractical due to polypropylene's drooping tendency and adhesion to nickel at these temperatures.

The degassed mix was then poured into the mold bordered by zinc chromate. Any bubbles entrained in the filled mold were removed by hand and/or vacuum degassed a second time. The primed glass was then placed edgewise onto the filled mold and slowly brought down until the mold was closed. The assembly was then placed in a press for curing at manufacturers' recommended cure times and temperatures. Very thin bubble-free castings were achievable by using the press. The project scope did not permit an optimization of each of these candidates in terms of cycle time and life cycle cost performance.

The time of application and magnitude of the cure-pressure were determined by trial-and-error. The press platens were in contact with the assembly at $O$ psig until gelation occurred. Pressure was then raised to 2 psig to force out any air bubbles. After curing, the flexible mold was removed, and the casting was trimmed, cleaned, and inspected.

Each candidate had problems in processability. Urethanes ND-2300 and SS-6640 had very short pot lives which disallowed adequate degassing by this technique. Also, bubble-free castings were difficult to attain due to the adhesion of air bubbles between the mold facets. The problem might be solved by using automatic metering, mixing and degassed resin. This would be cost-effective at some production volume level.

Silicone SS-5272Y(HT), with a viscosity of 300 poise, required a few hours for all bubbles to egress from the filled mold. RTV-670 was relatively easy to process. Silicones would also benefit from automatic equipment.

The problem encountered with silicone molds used in a press was that the mold facets distorted under the load. All castings were made since then with polypropylene molds only. The release of urethane castings from polypropylene was not as easy as was with silicone molds. 
Cure inhibition of silicones on new polypropylene molds was resolved by thorough solvent cleaning and repeated castings.

Candidate SS-6640 had to be dropped from further experimentation due to project limitations. It continued to have the problem of adherence to the flexible molds. All other candidates released from polypropylene without problems.

An effort was made to make castings as thin as possible in order to verify its feasibility. Facet-thin castings of both silicone and urethane candidates were made by pressing out the excess resin from the casting before gelation occurred. The urethane facets were pulled off the glass in some areas of the casting during the mold-release. A resin slab of 20-40 mils supporting the facets eliminated this problem. Silicone castings could be made facet-thin without this release problem. 


\section{CONCLUSIONS}

Optical efficiency of the glass-plastic lens is largely dictated by the solar energy light transmittance of the glass superstrate which is used. Using common soda lime glass the efficiency is about $10 \%$ below that of an acrylic lens. If iron-free glass were available the efficiencies would be expected to be comparable, with the glass-plastic only a few percentage points lower.

The life expectancy of glass-plastic lenses, however, is questionable when compared to acrylic. Readily available state of the art facet materials which are easily fabricated appear to be deficient in terms of long term durability (i.e., approaching a 20 year life or a life comparable to acrylic) in this application. Much more extensive testing than was conducted as a part of this project would be required in order to accurately characterize the life of the composite lenses.

Using the commercially available tempered soda lime glass, .125 inch thick and facet material about .040 inches thick on the average, material cost is:

Material Cost/Ft ${ }^{2}$

\begin{tabular}{|c|c|c|c|c|}
\hline & & Type 1 & Type 2 & Type 3 \\
\hline & $\begin{array}{l}\text { Soda lime glass, .125" } \\
\text { tempered }\end{array}$ & $\$ .65$ & $\$ .65$ & $\$ .65$ \\
\hline 0 & Urethane facets, .04" & .35 & & \\
\hline & Silicone facets, .04" & & 3.20 & \\
\hline & $\begin{array}{l}\text { Low cost resin facets, .04" (set) } \\
\text { mat. }\end{array}$ & $\$ 1.00$ & $\overline{\$ 3.85}$ & $\frac{.20}{\$ .85}$ \\
\hline
\end{tabular}

These costs are in truckload quantities. The Type 1 construction, using urethane facets, is thought to be representative of the medium cost plastic resin systems; Type 2, using silicone facets, is representative of expensive resin system in general; and Type 3 is estimated to be representative of general low cost resin systems. It appears that material costs of laminated vs monolythic acrylic lenses would be very comparable if a low cost resin system can be identified as a facet material. If this is the case, and if manufacturing costs remain comparable to that of acrylic casting then total lens cost of the composite lens would be expected to be comparable to that of cast acrylic at $\$ 2.50 / \mathrm{ft}^{2}$.

The $10 \%$ drop in optical efficiency of the glass-plastic lens requires a $40 \%$ drop in lens price for system costs to remain equal to that of the cast acrylic Fresnel lens. It would seem that at the present time this would be difficult to achieve.

If the Jeannette low iron soda-lime glass were used to obtain the higher light transmission the glass price would rise to about $\$ 1.00$ per square foot and in 
combination with a low cost resin at $\$ .20$ per square foot a material cost of $\$ 1: 20$ per square foot would be achieved. This combination would be much more attractive and not be subject to the drop in optical efficiency penalty associated with normal soda-lime glass.

A considerable amount of aditional work must be performed to develop low cost glass-acrylic Fresnel lenses. competative with cast acrylic lenses. The work required would focus primarily on both the development and testing of better facet material and on practical large scale manufacturing processes to produce the laminated lenses. 


\section{RECOMMENDATIONS FOR FURTHER WORK}

A number of areas which should be studied in order to further the development of laminated glass-plastic Fresnel lenses have been identified based on the work reported herein. These include:

\section{Noncastable Materials}

Materials which were not castable were excluded from this study. Materials which could be used in automated manufacturing processes such as injection, transfer or reaction injection molding should be explored. Exploration of such materials would lead to fabrication cost savings.

\section{Weatherable Epoxies}

Development work is being conducted by industry to improve the weatherability of flexible epoxies. These materials should be examined for application as a facet material as they become available.

\section{Urethanes}

Aliphatic polyester type urethanes with tailored UV and antioxidant stabilizers should be more environmentally stable than the urethanes studied in this project. The use of automatic military and mixing equipment would allow improved processing and could lead to acceptable facet manufacture processes.

\section{Silicones}

Silicone elastomers comprise a broad spectrum of compositions which could not be evaluated in this study. Silicones tailored for this application would be expected to both fabricate more readily and have better durability.

\section{Acrylates}

A variety of esters of acrylic acid lead to castable homo and copolymers of high flexibility and good weatherability. Development of such compositions were beyond the scope of this work but should be considered for future efforts.

\section{Glass}

Low iron soda lime glass manufactured by the float process has the potential of becoming a cost effective superstrate if market demand justifies production. Accumulation of applications which can generate this demand should be explored.

\section{Tooling}

The Fresnel lens mold design for generating plastic facets on glass can be greatly improved in terms of lens efficiency and automated lens ejection. Flexible type lens facet molds would appear to offer advantages in both cost and processing and should be explored. 


\section{Processing}

A reasonable process for manufacturing the glass-plastic Fresnel lens has not been identified. Processes should be generally explored for cost efficiencies and product qualities in the process volumes anticipated for such lenses. Highly automated processes would be most desirable.

\section{Optical Testing}

The ability to obtain consistent measurements of optical efficiency is not available at Swedlow for Fresnel lenses intended for solar application. Methods need to be improved as such measurements are crucial to alternate lens type evaluation.

\section{Optical Performance After Aging}

More work needs to be done in the evaluation of lenses after long term outdoor exposure. The lenses should be placed in configurations which are representative of expected field applications in order to obtain realistic evaluations. Tests conducted to date have been comparative in nature and are not applicable to life prediction. A variety of exposure conditions including EMMAQUA and multiple geographic exposure should be conducted. 


\section{REFERENCES}

1. Jebens, Robert W., Laminated Fresnel Lenses, Final Report on Sandia Laboratories Contract No. 07-7144, RCA Laboratories, August 1978.

2. Childers, Craig M.; Design and Development of Monolithic Acrylic Fresnel Lenses for Use in Point Focus PV Systems, SAND 81-7040, December 1981.

3. Matalon, Lawrence A., Test Report: Development of a Laminated GlassPlastic Fresnel Lens, July 21, 1980.

4. Hobbs, Robert B., Jr., Design and Development of a Laminated Fresnel Lens for Point Focus PV Systems, SAND 80-7137, January 1981.

5. Holdridge, D. W., Development of a 10X Lens Concentrator, Final Program Report to the U. S. Department of Energy, Albuquerque, N.M. for Contract No. EM-89-C-04-4197, March 1980.

6. Schuler, D. G., Introduction to the Photovoltaic Concentrator Workshop, Proceedings of the DOE Concentrator Systems Workshop. 


\section{Acurex Corporation (3) \\ Attn: George sutton Bob spencer John Kull}

485 Clyde Avenue Mountain View, CA 94042

Aerospace Corporation

Attn: Ed Simburger

2350 El Segundo BIvd.

El Segundo, CA 90266

Alliance mool corp.

Fresnel optics Division

Attn: Helmut walter

$1300 \mathrm{Mt}$. Read Blvd.

Rochester, NY 14606

Applied Solar Energy Corp.

Attn: Steve Olah

Frank Ho

Ken Ling

15251 E. Don Julian Road

City of Industry, CA 91746

ARCO power systems

Attn: Floyd Dlalit

Suite 307

7061 S. University Blva.

Littleton; CO 80122

Arizona State University (2)

Attn: Charles Backus Robert Sanderson

College of Engineering

Tempe, AZ 85281

Ray Bahm \& Associates

Attn: Ray Bahm

2513 Kinberly Court NW

Albuquerque, NM 87130

Battelle

Attn: Don Carmichael

505 King Avenue

Columbus, OH 43201
The BDM Corporation (3)

Attn: Tim Lambarski

Wayne Kaufiman

Bill schwinkendor

1801 Randolph Road SE

Albuquerque, NM 87111

Boeing Engineering \& Const. Co. Attn: Roger Gillette

P. O. Box 3707

Seattle, WA 98124

Burns \& Roe, Inc. (2)

Attn: G. A. Fontana

800 Kinderkamack Road

Oradell, NJ 07649

Chevron Research

Attn: John Cape

(2)

R. Creek

576 Standard Avenue

Richrnond, CA 94802

Cyro Industries

697 Route 46

clifton, NJ 07015

U. S. Dept. of Energy (2)

ALO

Attn: James Morley Ethan Walker

P. O. Box 5400

Albuquerque, NM 87115

U. S. Dept. of Energy (7)

Div. of PV Energy Technologies

Attn: M. B. Prince (5)

L. A. Barrett

A. Scollaro

1000 Independence Ave. SW

washington, DC 20585

\author{
E-Systems (2) \\ Attn: Mark O'Neill \\ A. J. McDanal \\ P. O. Box 226118 \\ Dallas, TX 752.66
}


General Electric Co.

Attn: Ron Hodge

P. O. Box 527

King of Prussia, PA 19406

International Rectifier

Attn: Harold Weinstein

235 Kansas Street

El Segundo, CA 91214

Intersol power Corporation

Attn: John Sanders

7400 W. Radcliff Avenue

Littleton, CO 80123

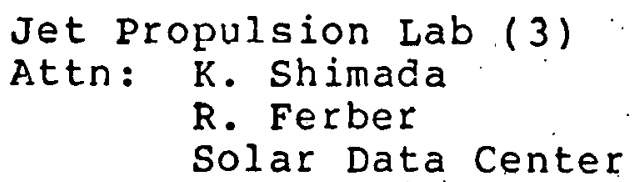

4800 Oak Grove Drive

Pasadena, CA 91109

Martin Marietta (4)

Attn: S. Broadbent

$R$. He in

D. Hughes

J. Baumann

P. O. Eox 179

Denver, CO 80201

Microwave Associates

Attn: Jonathon Chapple-Sokol

Bualh Avenue ME-116

Burlington, MA 01803

$3 M$

Attn: Sanford Cobb

Industrial Optics

$235 \quad 2 \mathrm{DI} 5$

$3 M$ Center

st. Paul, MN 55144

Motorola

Attn: Keith

Kingston

GED

8201 E. MCDowell

Scottsdale, AZ 85252
NASA, HQ

Attn: John Loria

Code. RET-1

Washington, DC 20546

New. Shelter Home Magazine 9317 Shoshone

Albuquerque, NM 87111

Oak Ridge National Lab

Attn: Steve Kaplan

P. O. Box $x$

Oak Ridge, TN 37830

Uklahoma Univelsily

571 South University Blva. Norman, OK

Photowatt (2)

Attn: william Taylor Mike Keeling

2414 W. 14 th Street

Tempe, AZ 85281

Powel Hybrias

Attn: Jeff Meyer

1742 Crenshaw Blvd. Torrance, CA 90501

PRC

Attn: E. Stirewalt 5201 Leesburg Pike: Suite 400

Falls Church, VA 22070

Purdue University (2)

Attn: Richard Schwartz Mark Lundstrom

Electrical Engineering: Dept. west Lafayette, IN 47907

Quantum Specialties

Attn: James E. Molle

163 Verde Circle

Rohnert Park, CA 94928 
Research Triangle Institute Attn: Mayrant Simons

Box 12194

Research Triangle Park, NC 27709

SERI (3)

Attn: Gene Blakeslee Lee Cole John Benner

16]7 Cole Blvd.

Golden, CO 80401

SERI, Library (2)

1536 Cole Blvd., Bldg. \#4

Golden, CO 80401

Southern Cal Edison

Attn: Spencer Carlisle

2244 Walnut Grove Ave.

Rosemead, CA 91770

Spectrolab

Attn: Brian Elm

12500 Gladstone Avenue

Sylmar, CA 91342

Spire (3)

Attn: S. Tobin

M. Nowlan

R. Little

Patriots Park

Bedford, MA 01730

Star Light Energy

Attn: J. Furber

171718 th street $\mathrm{NW}$

washington, DC 20009

Strategies unlimitea

201 San Antonio Circle

Suite 205

Mountain view, CA 94040
Thermo Electron

Attn: Ron Scharlack

45 First Avenue

waltham, MA 02154

UNM/NMERI

Attn: G. Leigh

Campus Box 25

Albuquerque, NM

87131

Varian \& Associates

Attn: Peter Borden

N. Kaminar

611 Hansen Way $\mathrm{K}-219$

Palo Alto, CA 94303

Wright Patterson AFB

Attn: Jack Geis

AFWAL/POOC

Wright Patterson AFB, $\mathrm{OH}$

Wyle Labs (2)

Attn: Dave Christenson

George Meares

7800 Governors Drive west

Huntsville, AL 35807

Swerlow, Inc. (2)

Attn: Gene Nixon

12122 Western Ave.

Garden Grove, CA 92645

Solar Works

Attn: Pauj. Wijkins

Route 2, Box 274

Santa Fe, NM 87501 
1133 R. Chaffin

1133 J. Wiczer

1811 R. Assink

1822 J. Sweet

Attn: M. Moss

R. Pettit

1823 M. Chamberlain

1845 R. Eagan

2142 B. Rose

2146 M. Garner

2146 B. Hanson

2146 B. Nasby

2146 J. Rodriguez

$2146 \mathrm{H}$. Weaver

9700 E. Beckner

9720 D. Schueler

9721 J. Banas

9721 H. Gerwin

9723 E. Burgess

9724 E. Boes

9724 D. Arvizu

9724 L. Beavis

9724 C. Chiang

9724 M. Edenburn

9724 D. King

9724 A. Maish

9724 M. Rios

9724 C. Stillwell (10)

3141 L. J. Erickson (5)

3151 W. L. Garner (3)

3154-3 C. H. Dalin (25)

For DOE/TIC (Unlimited Release)

8214 M. A. Pound 